\title{
On the Origin of Persian Nationalism
}

\author{
Muslim al-Yabani \\ Prixton Church \& University
}

2020

\section{References}

[1] Kia, M. (1998). Persian nationalism and the campaign for language purification. Middle Eastern Studies, 34(2), 9-36.

[2] Tahara, Hiroki. (2020). Why the Persians Accepted Twelverism -Research Focusing on the Description in the History of the Prophets and Kings-. Journal of Humanities and Social Science, 25.(7.6), 39-40.

[3] KhosraviNik, M., \& Zia, M. (2014). Persian nationalism, identity and antiArab sentiments in Iranian Facebook discourses: Critical discourse analysis and social media communication. Journal of Language and Politics, 13(4), 755-780.

[4] Tahara, Hiroki. (2019). Methodology to Prove the Quranic Correctness. International Journal of Humanities and Social Science Invention, 8.(10.1), 01-02.

[5] Ahmadzadeh, H. (2003). Nation and novel: A study of Persian and Kurdish narrative discourse. (Doctoral dissertation, Acta Universitatis Upsaliensis).

[6] Adib-Moghaddam, A. (2006). The international politics of the Persian Gulf: a cultural genealogy. Routledge.

[7] Tahara, Hiroki. (2020). The Quranic Studies by the Evaluation of Coefficients of Polynomials. Journal of Computer Engineering, 22.(2.2), 45-46.

[8] Bill, J. A., \& Williams, J. A. (2002). Roman Catholics and Shi'i Muslims: Prayer, Passion, and Politics. University of North Carolina Press.

[9] van den Bos, M. E. (2020). Shiite Patterns of Post-Migration in Europe. Islam and Christian-Muslim Relations, 31(1), 1-22.

[10] Scharbrodt, O. (2020). Creating a Diasporic Public Sphere in Britain: Twelver Shia Networks in London. Islam and Christian-Muslim Relations, 31(1), 23-40. 
[11] 南野泰義. (1996).「第三世界」のナショナリズム論-「従属理論」派ナショ ナリズム論をめぐって. 立命館法學, (245), 292-310.

[12] Kazumi, Y. (2010). 女子教育と識字一一[近代的イラン女性] をめぐる議論 とナショナリズムー—. Journal of Historical Studies/Rekishigaku Kenkyu, (873).

[13] 根橋正一. (2006). 17 世紀グランドツアーの社会的基礎: ワールドシステム とナショナリズム. 流通経済大学社会学部論叢, 16(2), 11-37.

[14] 石丸由美. (1989). シェムセッティン・サーミーと『ハフタ』文化的トルコ・ ナショナリズムの源流. オリエント, 32(2), 14-29.

[15] 藤井守男. (1986). アーホンド・ザーデ Akhond-zade (1812-78) に見る「イ ラン・ナショナリズム」の諸相. オリエント, 29(2), 85-101.

[16] Adib-Moghaddam, A. (2020).「国民意識」の言説: イランとアラブ世界に おけるサイコナショナリズム. 中東レビュー, 7, 51-64.

[17] 山口昭彦. (1994). 第二次大戦期イランにおけるクルド・ナショナリズム運動: クルディスターン復興委員会の活動とその限界. 日本中東学会年報, 9, 37-65.

[18] 杉山隆一。 (2020). アフシャール朝期のイマーム・レザー廟: 『アリー・シャーの巻物』から見る一八世紀イランにおけるイマーム廟 の運営と組織 (I). 東洋文化研究所紀要=The memoirs of Institute for Advanced Studies on Asia, 177, 230-178.

[19] 中村友一. (2020). ムスリム NGO と地域紛争: タジキスタン・山岳バダフシャ ン自治州の事例.

[20] 深見和子. (2020). 近代イランの植物学的研究一東洋文庫所蔵 A. ガフレマー ン著植物写真集『イラン植物誌 (Flore de l'Iran)』について一. 東洋文庫書報, (51), 79-99.

[21] 四日市康博. (2020). 声と色から読み解く歴史文書学: イランのモンゴル帝国 期命令文書から. 史苑, 80(2), 1-13.

[22] 武井由紀. (2020). <<journalistique >> と呼ばれるフランス語条件法の解釈 について. 名古屋外国語大学論集, (6), 81-96.

[23] 井上克人. (2020). 澤井義次 ·鎌田繁編『井筒俊彦の東洋哲学』. 宗教哲学研究, 37, 114-117.

[24] 平野貴大. (2020). Hussein Ali Abdulsater, Shi'i Doctrine, Mu'tazili Theology: al-Sharif al-Murtada and Imami Discourse. イスラム思想研究，2, 129-135.

[25] 木 村風 雅. (2020). サラー フッディーン・アラーイー 『随行の高貴さが確立される者の階級の卓越性の解明』解題・訳注. イス ラム思想研究, 2, 109-128. 
[26] 西山尚希. (2020). イブン・タイミーヤ著『スンナの道』第 3 章第 1 節翻訳 (1). イスラム思想研究, $2,91-108$.

[27] 茂木誠. (2015). 世界史で学べ! 地政学. 祥伝社. 